\title{
Effect of repeated exposure to aniline, nitrobenzene, and benzene on liver microsomal metabolism in the rat
}

\author{
JUSTYNA M. WIŚNIEWSKA-KNYPL, JANINA K. JABŁOŃSKA, \\ and JERZY K. PIOTROWSKI \\ Department of Biochemistry, Institute of Occupational Medicine, 90-950 Lodz, \\ Teresy, 8, P.O. Box 199, Poland
}

\begin{abstract}
Wišniewska-Knypl, Justyna M., Jabłońska, Janina K., and Piotrowski, Jerzy K. (1975). British Journal of Industrial Medicine, 32, 42-48. Effect of repeated exposure to aniline, nitrobenzene, and benzene on liver microsomal metabolism of the rat. Exposure of rats to aniline at daily doses of $50 \mathrm{mg} / \mathrm{kg}$ of body weight over a month stimulated the microsomal metabolism as manifested by (1) acceleration of p-hydroxylation of aniline and N-demethylation of aminopyrine in $9.000 \times \mathrm{g}$ postmitochondrial supernatant of the liver, (2) shortening the sleeping time after hexobarbital, and (3) reduction of the antipyretic effect of phenacetin.

In the rats exposed to nitrobenzene in a similar manner to aniline, nitroreduction of nitrobenzene and p-hydroxylation of aniline remained unaffected; the antipyretic effect of phenacetin was decreased, whereas hexobarbital sleeping time remained unchanged.

Exposure of rats to benzene ( $50 \mathrm{mg} / \mathrm{kg}$ of body weight daily for a month) had no effect on the rate of hydroxylation of benzene and N-demethylation of aminopyrine. In benzeneexposed rats hexobarbital sleeping time was prolonged whereas the antipyretic effect of phenacetin was unaffected.

Microsomal metabolism of aniline, nitrobenzene, and benzene was stimulated and inhibited when the rats were pretreated with phenobarbital and SKF 525-A, respectively.
\end{abstract}

The traditional approach to problems of industrial toxicology allows certain conclusions to be drawn based on controlled experiments in which a single dose of a poison is administered to the intact human and its metabolism studied. This is especially true for exposure tests which are further applied for men exposed daily in industry. This procedure is justified only if the compound in question is equally metabolized when administered once or repeatedly. The body burden as well as the excretion rate due to daily exposure may then be computed on a basis of kinetic data obtained from a single dose experiment (Piotrowski, 1971).

Metabolism of most foreign compounds is catalysed by reduced nicotinamide adenine dinucleotide phosphate (NADPH)—dependent micro- somal enzymes in the liver (Gillette, 1966). Activity of the enzyme system may be stimulated unspecifically by a number of foreign compounds, and exposure to one compound can in turn lead to accelerated metabolism of others, applied later.

The assumption about the constant rate of metabolism of industrial poisons applied once and repeatedly needs to be verified in view of reports that stimulation of activity of microsomal enzymes may take place under the influence of a variety of drugs and chemicals (Conney and Burns, 1963).

This study was undertaken in order to test whether repeated exposure of rats to aniline, nitrobenzene, and benzene may finally lead to stimulation of the rate of microsomal metabolism of the compounds. 


\section{Materials and methods}

\section{Animals and treatments}

Male albino rats of the Wistar strain, body weight 200-250 g, were used. The rats were caged in groups and were fed a commercial laboratory chow MURIGRAN and tap water ad libitum.

Aniline, nitrobenzene, and benzene in the prolonged experiments were given daily subcutaneously for a month at doses of 5 and $50 \mathrm{mg} / \mathrm{kg}$ of body weight. An emulsion in $0.1 \%$ aqueous Tween 80 was used for injection. In short duration tests rats were injected with the same substances at doses of $150 \mathrm{mg} / \mathrm{kg}$ of body weight daily for three days. The controls received $0 \cdot 1 \%$ Tween 80.

The classical inducers of the drug-metabolizing microsomal enzymes, phenobarbital and 3,4-benzpyrene, as well as the inhibitor SKF 525-A (2-diethylaminoethyl-2, 2-diphenylvalerate hydrochloride) (Conney and Burns, 1963; Gillette, 1966) have been used in the study as reference substances. Phenobarbital sodium in physiological saline was given intraperitoneally four times at 24-hour intervals in doses of $80 \mathrm{mg} / \mathrm{kg}$ of body weight according to Conney and Burns (1963). 3,4-Benzpyrene in olive oil was given according to Rickert and Fouts (1970) once intraperitoneally at a dose of $45 \mathrm{mg} / \mathrm{kg}$ 72 hours prior to an antipyretic test with phenacetin. SKF 525-A in physiological saline was given according to Kato, Chiesara, and Vassanelli (1962) once intraperitoneally at a dose of $50 \mathrm{mg} / \mathrm{kg}$ of body weight 30 minutes prior to (1) the killing of animals for in vitro assays of drug-metabolizing enzyme activity, or (2) before the administration of hexobarbital for the sleeping-time tests. In the case of antipyretic tests SKF 525-A was given in a dose of $25 \mathrm{mg} / \mathrm{kg}$ of body weight 45 minutes before phenacetin (Conney et al., 1966).

Concurrent control groups to all test groups were handled in the same manner and injected with the proper vehicles, omitting the test-chemicals.

\section{In vitro assays of liver drug-metabolizing enzymes}

Rats were killed by decapitation. Liver was weighed, chilled on ice, and homogenized with 3 volumes of $\mathrm{KCl}$ (150 mmol)-Tris-HCl (20 mmol)-EDTA-Na (1 mmol) buffer, $\mathrm{pH} 7 \cdot 4$, in a glass Potter-Elvehjem homogenizer with a Perspex pestle. The homogenates were centrifuged at $9000 \times \mathrm{g}$ for 15 minutes at $4^{\circ}$; the supernatants were aspirated and directly used for enzymatic assays.

Oxidative reactions were carried out in air and reductive ones under nitrogen. The $9000 \times \mathrm{g}$ supernatant of the liver was used as the enzyme source for transformations of substrate and for generation of NADPH and it was supplemented with suitable substrates and cofactors. Incubation was performed at $37^{\circ}$ in a Dubnofftype metabolic shaker (100 oscillations per min). To insure adequate agitation of incubation medium two glass marbles were put into each flask.

The rate of aniline hydroxylation to p-aminophenol was measured for 15 minutes (Holtzman and Gillette, 1969) in a final volume of $3 \mathrm{ml}$ suspension consisting of: Tris- $\mathrm{HCl}$ buffer, $\mathrm{pH} 7 \cdot 4(50 \mathrm{mmol}), \mathrm{MgCl}_{2}(5 \mathrm{mmol})$, NADP $(0.5 \mathrm{mmol})$, glucose 6 -phosphate $(10 \mathrm{mmol})$, aniline hydrochloride $(1 \mathrm{mmol})$, and $1 \mathrm{ml}$ of $9000 \times \mathrm{g}$ tissue supernatant. Reaction was stopped by cooling the flasks on ice and, after extraction, p-aminophenol was determined colorimetrically by means of the indophenol reaction.

The rate of aminopyrine $\mathrm{N}$-demethylation to yield formaldehyde was measured according to Dewaide and Henderson (1968) for 15 minutes. The reaction mixture in a final volume of $5 \mathrm{ml}$ consisted of: Tris- $\mathrm{HCl}$ buffer pH 7.4 (50 mmol), semicarbazide hydrochloride $(5 \mathrm{mmol})$, $\mathrm{MgCl}_{2}(0.8 \mathrm{mmol}), \mathrm{MnCl}_{2}(0.008 \mathrm{mmol})$, NADP (0.088 $\mathrm{mmol})$, glucose 6-phosphate $(5 \mathrm{mmol})$, aminopyrine $(16.7 \mathrm{mmol})$, and $1 \mathrm{ml}$ of the supernatant. Reaction was stopped by precipitation of protein with $1 \mathrm{ml}$ of $25 \%$ $\mathrm{ZnSO}_{4}$ and $1 \mathrm{ml}$ of saturated $\mathrm{Ba}(\mathrm{OH})_{2}$. The precipitate was removed by centrifugation and the amount of formaldehyde produced in the supernatant was determined according to Cochin and Axelrod (1959), a modification of the original Nash (1953) method.

The rate of benzene hydroxylation to phenol was measured for 30 minutes in a medium described by Lal, Puri, and Fuller (1970): the reaction mixture in a final volume of $8 \mathrm{ml}$ consisted of sodium phosphate buffer, pH 7.4 (50 mmol), $\mathrm{MgCl}_{2}$ (3 mmol), nicotinamide (25 mmol), NADP $(0.16 \mathrm{mmol})$, glucose 6-phosphate $(6.25 \mathrm{mmol})$, saturated level of benzene $(99 \mathrm{mmol})$, and $2 \mathrm{ml}$ of the supernatant. The reaction was stopped by cooling in an ice-bath. Steam-distilled phenol was determined colorimetrically with 2,6-dibromochinonochlor oimide as described by Dutkiewicz, Piotrowski, and Kęsy-Dąbrowska (1964).

Reduction of nitrobenzene to aniline was assayed in a medium (Fouts and Brodie, 1957) containing sodium phosphate buffer, $\mathrm{pH} 7 \cdot 4(80 \mathrm{mmol}), \mathrm{MgCl}_{2}(5 \mathrm{mmol})$, nicotinamide $(20 \mathrm{mmol})$, NADP $(0 \cdot 12 \mathrm{mmol})$, glucose 6 -phosphate $(5 \mathrm{mmol})$, nitrobenzene $(1 \mathrm{mmol} ; 5 \mu \mathrm{l}$ of $10 \%$ nitrobenzene in $98 \%$ ethanol, $\mathrm{v} / \mathrm{v}$ ), and $1 \mathrm{ml}$ of the supernatant. The reaction was run for 15 minutes and stopped by cooling in an ice-bath. Protein was precipitated with $5 \%$ trichloroacetic acid, and in the clear supernatant aniline was determined after diazotization by coupling with 1-naphthol (Salm, 1958).

Protein was determined according to Lowry, Rosebrough, Farr, and Randall (1951), using bovine serum albumin (fraction V) as a standard.

Student's $t$ test was used for statistical evaluation of the results.

Indirect in vivo assay of microsomal metabolism rate In order to evaluate the effect of the investigated substances on the rate of biotransformation in the intact organism additional unspecific tests were used. These were based on the duration of effects of standard drugs, which depends upon the activity of microsomal enzymes of liver cells.

(1) Hexobarbital sleeping time: Sleeping time was determined in rats injected with intraperitoneal 125 $\mathrm{mg} / \mathrm{kg}$ body weight sodium hexobarbital in physiological saline according to Conney and Burns (1963). The time that had elapsed between losing and regaining the righting reflex was designated as sleeping time.

(2) Antipyretic activity of phenacetin: This test was performied on fevered rats according to Conney et al. (1966). The fever was induced by subcutaneous administration of $10 \mathrm{ml} / \mathrm{kg}$ body weight of $30 \%$ brewers' 
yeast suspension in physiological saline. Phenacetin suspended in $2 \%$ gum acacia was administered by gavage at a dose of $200 \mathrm{mg} / \mathrm{kg}$ body weight 15 hours after the hyperthermia had been induced. Rectal temperature was taken hourly for four hours with an ELLAB Electric thermometer (ELLAB Instruments, Copenhagen).

Phenacetin in vivo is metabolized to pharmacologically inactive $\mathrm{N}$-acetyl-p-aminophenol (Conney et al, 1966). The pharmacological effectiveness of the former is decreased when the process is accelerated and vice versa. Thus, opposite effects are produced by 3,4benzpyrene (inductor) and SKF 525-A (inhibitor).

Other compounds used in these two tests were administered as described above under "Animals and treatments".

\section{Results}

Aniline

The activity of microsomal enzymes after shortduration exposure and prolonged administration of aniline to rats is presented in Table 1. Prolonged as well as short-duration treatment of rats with aniline increased activity of aniline p-hydroxylase. An enhanced rate of $\mathrm{N}$-demethylation of aminopyrine was observed only after one month's exposure to the higher dose of the compound $(50 \mathrm{mg} / \mathrm{kg}$ body weight). It should be stressed, however, that the increment of activity of these enzymes was relatively scanty in comparison with the effect produced by phenobarbital.

\section{Nitrobenzene}

Attempts to reproduce in vitro the reaction of nitrobenzene hydroxylation to p-nitrophenol, which is considered the main metabolite both in humans and in rats, failed. Most probably the benzene ring was further hydroxylated to 4-nitrocatechol in the optimized in vitro system applied in this study.

Data concerning two other reactions involved in nitrobenzene metabolism are given in Table 2.

Exposure to nitrobenzene led to slight stimulation of activity of the microsomal enzymes. In the animals exposed for three days to the highest dose of nitrobenzene, $150 \mathrm{mg} / \mathrm{kg}$ of body weight, the activity of nitrobenzene nitroreductase was enhanced by about $50 \%$. One month's exposure to $5 \mathrm{mg} / \mathrm{kg}$ of body weight daily of nitrobenzene led to $50 \%$ stimulation of activity of aniline p-hydroxylase. Phenobarbital, which was used in comparative tests, enhanced activity of the enzymes by about $100 \%$.

\section{Benzene}

Neither the activity of benzene hydroxylase nor the activity of aminopyrine $\mathrm{N}$-demethylase was modified by the treatment of rats with benzene (Table 3).

Benzene hydroxylase is an inducible enzyme: its activity in phenobarbital pretreated rats increased fourfold over the control value. On the other hand, SKF 525-A inhibited the hydroxylation of benzene. Induction of the NADPH-dependent microsomal enzymes is usually accompanied by an increment of

TABLE 1

Effect of Prolonged Exposure of Rats to Aniline on Activity of Drug-metabolizing Enzymes in $9000 \times$ g Supernatant of Liver: Animals treated with Phenobarbital and SKF 525-A SERVED AS REFERENCE CONTROLS

\begin{tabular}{|c|c|c|c|}
\hline Group & Treatment & $\begin{array}{l}\text { Aniline p-hydroxylase } \\
\text { (nmols of p-aminophenol } \\
\text { per mg protein per } 15 \text { min }^{1} \text { ) }\end{array}$ & $\begin{array}{c}\text { Aminopyrine } N \text {-demethylase } \\
\text { (nmols of formaldehyde } \\
\text { per } \mathrm{mg} \text { protein per } 15 \mathrm{~min} \text { ) }\end{array}$ \\
\hline $\begin{array}{l}\text { Control, } 0.1 \% \text { Tween } 80 \\
\text { Aniline in } 0.1 \% \text { Tween } 80\end{array}$ & $\begin{array}{r}1 \mathrm{ml} / \mathrm{kg}^{6} \text { daily for } 3 \text { days } \\
150 \mathrm{mg} / \mathrm{kg}^{2} \text { daily for } 3 \text { days }\end{array}$ & $\begin{array}{l}1 \cdot 7 \pm 0 \cdot 13 \\
2 \cdot 2 \pm 0 \cdot 08^{3}\end{array}$ & $\begin{array}{l}\text { ND }^{5} \\
\text { ND }\end{array}$ \\
\hline $\begin{array}{l}\text { Control, } 0.1 \% \text { Tween } 80 \\
\text { Aniline in } 0.1 \% \text { Tween } 80\end{array}$ & $\begin{array}{r}1 \mathrm{ml} / \mathrm{kg} \text { daily for } 30 \text { days } \\
5 \mathrm{mg} / \mathrm{kg} \text { daily for } 30 \text { days } \\
50 \mathrm{mg} / \mathrm{kg} \text { daily for } 30 \text { days }\end{array}$ & $\begin{array}{l}1 \cdot 9 \pm 0.06 \\
2 \cdot 3 \pm 0.08^{3} \\
2 \cdot 5 \pm 0 \cdot 10^{3}\end{array}$ & $\begin{array}{l}18 \cdot 8 \pm 0 \cdot 7 \quad(11) \\
19 \cdot 7 \pm 1 \cdot 0 \quad(10) \\
27 \cdot 1 \pm 1 \cdot 5^{4}\end{array}$ \\
\hline $\begin{array}{l}\text { Control, } 0.9 \% \mathrm{NaCl} \\
\text { Phenobarbital in } 0.9 \% \mathrm{NcCl} .\end{array}$ & $\begin{array}{l}1 \mathrm{ml} / \mathrm{kg} \text { daily for } 4 \text { days } \\
80 \mathrm{mg} / \mathrm{kg} \text { daily for } 4 \text { days }\end{array}$ & $\begin{array}{l}2 \cdot 3 \pm 0.12 \\
5 \cdot 0 \pm 0.50^{3}\end{array}$ & $\begin{array}{l}\text { ND } \\
\text { ND }\end{array}$ \\
\hline $\begin{array}{l}\text { Control, } 0.9 \% \mathrm{NaCl} \ldots \\
\text { SKF } 525-\mathrm{A} \text { in } 0.9 \% \mathrm{NaCl}^{2}\end{array}$ & $\begin{array}{c}1 \mathrm{ml} / \mathrm{kg} \text { once } \\
50 \mathrm{mg} / \mathrm{kg} \text { once }\end{array}$ & $\begin{array}{l}2 \cdot 2 \pm 0.05 \\
1.2 \pm 0.02^{3}\end{array}$ & $\begin{array}{l}\text { ND } \\
\text { ND }\end{array}$ \\
\hline
\end{tabular}

${ }^{1}$ Mean value \pm standard error. Number of animals in each test group in parentheses.

2 SKF 525-A was injected intraperitoneally 30 min prior to killing the animals. In all other groups the last administration was 24 hours before killing.

3,4 Significantly different from the control at $\mathbf{P}=0.01$ or 0.001 , respectively.

Not determined.

'Body weight. 
TABLE 2

ACTIVITY OF DRUG-METABolizing ENZYMES IN $9000 \times \mathrm{g}$ SUPERNATANT OF Liver OF RATS With Prolonged Exposure to Nitrobenzene. Rats treated with Phenobarbital and SKF 525-A WERE USED AS CONTROLS

\begin{tabular}{|c|c|c|c|c|c|c|c|}
\hline \multirow{2}{*}{ 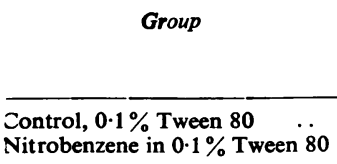 } & \multirow{2}{*}{$\begin{array}{r}\text { Treatment } \\
1 \mathrm{ml} / \mathrm{kg}^{5} \text { daily for } 3 \text { days } \\
150 \mathrm{mg} / \mathrm{kg} \text { daily for } 3 \text { days }\end{array}$} & \multicolumn{2}{|c|}{$\begin{array}{l}\text { Nitrobenzene reductase } \\
\text { (nmols of aniline per mg } \\
\text { protein per } 15 \text { min }^{1} \text { ) }\end{array}$} & \multicolumn{2}{|c|}{$\begin{array}{l}\text { Aniline p-hydroxylase } \\
\text { (nmols of p-aminophenol } \\
\text { per mg protein per } 15 \mathrm{~min} \text { ) }\end{array}$} & \multicolumn{2}{|c|}{$\begin{array}{l}\text { Aminopyrine } N \text {-demethylase } \\
(\mathrm{nmols} \text { of formaldehyde } \\
\text { per } \mathrm{mg} \text { protein per } 15 \mathrm{~min})\end{array}$} \\
\hline & & $\begin{array}{l}8 \cdot 7 \pm 0 \cdot 8 \\
13 \cdot 9 \pm 2 \cdot 0^{2}\end{array}$ & $\begin{array}{l}\text { (5) } \\
(5)\end{array}$ & $\begin{array}{l}1 \cdot 8 \pm 0 \cdot 1^{1} \\
1 \cdot 9 \pm 0.1\end{array}$ & $\begin{array}{l}(5) \\
(5)\end{array}$ & $\begin{array}{l}18.7 \pm 0.5^{1} \\
18.7 \pm 0.8\end{array}$ & $\begin{array}{l}(5) \\
(5)\end{array}$ \\
\hline $\begin{array}{l}\text { Control, } 0.1 \% \text { Tween } 80 \\
\text { Nitrobenzene in } 0.1 \% \text { Tween } 80\end{array}$ & $\begin{array}{r}1 \mathrm{ml} / \mathrm{kg} \text { daily for } 30 \text { days } \\
5 \mathrm{mg} / \mathrm{kg} \text { daily for } 30 \text { days } \\
50 \mathrm{mg} / \mathrm{kg} \text { daily for } 30 \text { days }\end{array}$ & $\begin{array}{r}7.4 \pm 1 \cdot 2 \\
10.5 \pm 0.7 \\
9.9 \pm 0.8\end{array}$ & $\begin{array}{l}(7) \\
(7) \\
(6)\end{array}$ & $\begin{array}{l}1 \cdot 7 \pm 0 \cdot 1 \\
2 \cdot 5 \pm 0 \cdot 1^{2} \\
2 \cdot 0 \pm 0 \cdot 1\end{array}$ & $\begin{array}{l}\text { (7) } \\
\text { (7) } \\
\text { (7) }\end{array}$ & $\begin{array}{l}13.7 \pm 1.2 \\
17.7 \pm 1.6 \\
15.8 \pm 1.6\end{array}$ & $\begin{array}{l}\text { (7) } \\
(7) \\
\text { (7) }\end{array}$ \\
\hline $\begin{array}{l}\text { Control, } 0.9 \% \mathrm{NaCl} \\
\text { Phenobarbital in } 0.9 \% \mathrm{NaCl} . .\end{array}$ & $\begin{array}{l}1 \mathrm{ml} / \mathrm{kg} \text { daily for } 4 \text { days } \\
80 \mathrm{mg} / \mathrm{kg} \text { daily for } 4 \text { days }\end{array}$ & $\begin{array}{r}7 \cdot 5 \pm 0 \cdot 2 \\
15 \cdot 4 \pm 1 \cdot 0^{2}\end{array}$ & $\begin{array}{l}(5) \\
(5)\end{array}$ & $\begin{array}{l}2 \cdot 3 \pm 0 \cdot 1 \\
5 \cdot 0 \pm 0 \cdot 1^{2}\end{array}$ & $\begin{array}{l}\text { (6) } \\
\text { (6) }\end{array}$ & $\begin{array}{l}14.5 \pm 0.7 \\
21.6 \pm 0.6^{2}\end{array}$ & $\begin{array}{l}(5) \\
(5)\end{array}$ \\
\hline $\begin{array}{l}\text { Control, } 0.9 \% \mathrm{NaCl} \quad \ldots \\
\text { SKF } 525-\mathrm{A} \text { in } 0.9 \% \mathrm{NaCl}\end{array}$ & $\begin{array}{c}1 \mathrm{ml} / \mathrm{kg} \text { once } \\
50 \mathrm{mg} / \mathrm{kg} \text { once }\end{array}$ & $\begin{array}{r}10.9 \pm 0.85^{3} \\
5 \cdot 4 \pm 0.70^{3}\end{array}$ & $\begin{array}{l}(4) \\
(4)\end{array}$ & $\begin{array}{l}\text { ND } \\
\text { ND }\end{array}$ & & $\begin{array}{l}\text { ND } \\
\text { ND }\end{array}$ & \\
\hline
\end{tabular}

${ }^{1}$ Mean values are followed by standard error. Number of animals in each group in parentheses.

2, s Significantly different from the control at $P=0.05$ and 0.01 , respectively.

Not determined.

${ }^{3}$ Body weight.

Other details as in Table 1.

microsomal protein content per whole liver and the increment of weight of the liver per $100 \mathrm{~g}$ of body weight (Conney and Burns, 1963). This was not the case in this study. The question arises how significant might be the in vitro recorded increments of the enzyme's activity for the in vivo rate of metabolism of foreign compounds. To solve this question the duration of hexobarbital narcosis and the antipyretic effect of phenacetin were measured in animals that had been exposed for a month to aniline, nitrobenzene, and benzene at doses of $50 \mathrm{mg} / \mathrm{kg}$ of body weight/day.

Results of these indirect in vivo assays corroborated the results of the in vitro tests.

Hexobarbital sleeping time was shortened in the rats exposed to aniline (Table 4). It remained unchanged in the rats exposed to nitrobenzene, and it was prolonged in the benzene-exposed rats. The

TABLE 3

Activity of Drug-metabolizing Enzymes in $9000 \times$ g Supernatant of Liver of Rats with Prolonged Exposure to Benzene. Rats treated with Phenobarbital and SKF 525-A were INCLUDED AS CONTROLS

\begin{tabular}{|c|c|c|c|c|}
\hline Group & Treatment & \multicolumn{2}{|c|}{$\begin{array}{l}\text { Benzene hydroxylase } \\
\text { (nmols of phenol } \\
\left.\text { per mg protein per } 15 \mathrm{~min}^{1}\right)\end{array}$} & $\begin{array}{l}\text { Aminopyrine } N \text {-demethylase } \\
\text { (nmols of formaldehyde } \\
\text { per mg protein per } 15 \text { min) }\end{array}$ \\
\hline $\begin{array}{l}\text { Control, } 0.1 \% \text { Tween } 80 \\
\text { Benzene in } 0.1 \% \text { Tween } 80\end{array}$ & $\begin{array}{r}1 \mathrm{ml} / \mathrm{kg}^{5} \text { daily for } 3 \text { days } \\
150 \mathrm{mg} / \mathrm{kg} \text { daily for } 3 \text { days }\end{array}$ & $\begin{array}{l}3 \cdot 4 \pm 0 \cdot 3 \\
3 \cdot 9 \pm 0 \cdot 2\end{array}$ & $\begin{array}{l}(6) \\
(6)\end{array}$ & $\begin{array}{l}17 \cdot 7 \pm 1 \cdot 3 \quad(6) \\
19 \cdot 5 \pm 2 \cdot 1 \quad(6)\end{array}$ \\
\hline $\begin{array}{l}\text { Control, } 0.1 \% \text { Tween } 80 \\
\text { Benzene in } 0.1 \% \text { Tween } 80\end{array}$ & $\begin{array}{r}1 \mathrm{ml} / \mathrm{kg} \text { daily for } 30 \text { days } \\
5 \mathrm{mg} / \mathrm{kg} \text { daily for } 30 \text { days } \\
50 \mathrm{mg} / \mathrm{kg} \text { daily for } 30 \text { days }\end{array}$ & $\begin{array}{l}3 \cdot 6 \pm 0.5 \\
3 \cdot 7 \pm 0.5 \\
4 \cdot 3 \pm 0.4\end{array}$ & $\begin{array}{l}(6) \\
(6) \\
(6)\end{array}$ & $\begin{array}{l}26 \cdot 1 \pm 2 \cdot 3 \quad(6) \\
27 \cdot 2 \pm 1 \cdot 3 \quad(6) \\
30 \cdot 3 \pm 2 \cdot 9 \quad(6)\end{array}$ \\
\hline $\begin{array}{l}\text { Control, } 0.9 \% \mathrm{NaCl} \\
\text { Phenobarbital in } 0.9 \% \mathrm{NaCl} \text {. }\end{array}$ & $\begin{array}{l}1 \mathrm{ml} / \mathrm{kg} \text { daily for } 4 \text { days } \\
80 \mathrm{mg} / \mathrm{kg} \text { daily for } 4 \text { days }\end{array}$ & $\begin{aligned} 4 \cdot 4 & \pm 0 \cdot 8 \\
18 \cdot 4 & \pm 2 \cdot 7^{3}\end{aligned}$ & $\begin{array}{l}(6) \\
(6)\end{array}$ & $\begin{array}{l}\text { ND } \\
\text { ND }\end{array}$ \\
\hline $\begin{array}{l}\text { Control, } 0.9 \% \mathrm{NaCl} \ldots \\
\text { SKF } 525-\mathrm{A} \text { in } 0.9 \% \mathrm{NaCl}\end{array}$ & $\begin{array}{c}1 \mathrm{ml} / \mathrm{kg} \text { once } \\
50 \mathrm{mg} / \mathrm{kg} \text { once }\end{array}$ & $\begin{array}{l}5 \cdot 5 \pm 0 \cdot 2 \\
2 \cdot 8 \pm 0 \cdot 4^{2}\end{array}$ & $\begin{array}{l}(4) \\
(4)\end{array}$ & $\begin{array}{l}\text { ND } \\
\text { ND }\end{array}$ \\
\hline
\end{tabular}

${ }^{1}$ Mean values are followed by the standard error. Number of animals in parentheses.

2, ${ }^{3}$ Significantly different from the control at $P=0.05$ and 0.01 , respectively.

${ }^{4}$ Not determined.

Other details as in Table 1.

${ }^{5}$ Body weight. 
TABLE 4

Hexobarbital Sleeping Time of Rats with Prolonged Exposure to Aniline, Nitrobenzene, and Benzene. Rats Pretreated with Phenobarbital and SKF 525-A were included as Controls

\begin{tabular}{|c|c|c|c|c|}
\hline Group & & & Treatment & Sleeping time (minutes) $)^{1}$ \\
\hline $\begin{array}{l}\text { Control, } 0.1 \% \text { Tween } 80 \ldots \\
\text { Aniline in } 0.1 \% \text { Tween } 80 \ldots \\
\text { Nitrobenzene in } 0.1 \% \text { Tween } 80 \\
\text { Benzene in } 0.1 \% \text { Tween } 80\end{array}$ & $\begin{array}{l}\cdots \\
\cdots \\
\cdots \\
\cdots\end{array}$ & $\begin{array}{l}\cdots \\
\cdots \\
\cdots \\
\cdots\end{array}$ & $\begin{array}{l}1 \mathrm{ml} / \mathrm{kg}^{5} \text { daily for } 30 \text { days } \\
50 \mathrm{mg} / \mathrm{kg} \text { daily for } 30 \text { days } \\
50 \mathrm{mg} / \mathrm{kg} \text { daily for } 30 \text { days } \\
50 \mathrm{mg} / \mathrm{kg} \text { daily for } 30 \text { days }\end{array}$ & $\begin{array}{l}25 \pm 0.9 \\
20 \pm 0.8^{2} \\
23 \pm 1.4 \\
30 \pm 0.7^{2}\end{array}$ \\
\hline $\begin{array}{l}\text { Control, } 0.9 \% \mathrm{NaCl} \\
\text { Phenobarbital in } 0.9 \% \mathrm{NaCl} \\
\text { SKF 525-A in } 0.9 \% \mathrm{NaCl}^{4}\end{array}$ & $\begin{array}{l}\cdots \\
\cdots \\
\cdots\end{array}$ & $\begin{array}{l}\cdots \\
\cdots \\
\cdots\end{array}$ & $\begin{array}{l}1 \mathrm{ml} / \mathrm{kg} \text { daily for } 4 \text { days } \\
80 \mathrm{mg} / \mathrm{kg} \text { daily for } 4 \text { days } \\
50 \mathrm{mg} / \mathrm{kg} \text { once }\end{array}$ & $\begin{array}{l}23 \pm 0.9 \quad \text { (5) } \\
14 \pm 1 \cdot 0^{3} \quad(5) \\
320(180-420)\end{array}$ \\
\hline
\end{tabular}

${ }^{1}$ Mean values are followed by the standard error. Number of animals in each test group in parentheses.

${ }^{2,3}$ Significantly different from the control at $P=0.01$ or 0.001 respectively.

4SKF 525-A was injected $30 \mathrm{~min}$ prior to the dose of hexobarbital $(125 \mathrm{mg} / \mathrm{kg}$ body weight) while the last dose of the remaining chemicals was given 24 hours earlier.

${ }^{5}$ Body weight.

inhibitor SKF-525-A and the inducer phenobarbital prolonged and shortened respectively the hexobarbital sleeping times.

The animals treated with aniline and nitrobenzene hardly ever reacted to phenacetin. The yeast provoked fever was only slightly decreased (Figure). Similar results were noted with the inducer 3,4benzpyrene in the reference tests. SKF 525-A intensified the antipyretic effect of phenacetin.

Exposure of rats to benzene had no influence on the antipyretic activity of phenacetin.

\section{Discussion}

It has been reported that (1) rabbits exposed for 18 to 26 days to very low doses of aniline show an increased rate of excretion of p-aminophenol in the urine (Minkina, Lublina, Chekunova, and Dobrynina, 1970), and (2) aniline-adapted rats show an increased tolerance to injection of $300 \mathrm{mg} / \mathrm{kg}$ body weight of aniline (Lublina, Minkina, and Rylova, 1971). Both phenomena can be explained by the results of this study, namely, that repeated administration of aniline to rats leads to stimulation of the microsomal metabolism.

Benzene had no effect on the activity of the microsomal enzymes (Table 3) or on the antipyretic activity of phenacetin (Figure). Earlier Cornish, Wilson, and Abar (1970) reported that this compound at single doses of $100 \mathrm{mg}$ per rat was inactive in respect of the microsomal hydroxylating system. Benzene may stimulate the microsomal metabolism in rats, mice, and rabbits but very high doses of about 1 to $2 \mathrm{~g}$ per $\mathrm{kg}$ of body weight must be used (Gonasun, Witmer, Kocsis, and Snyder, 1973). Nevertheless benzene at low doses of $50 \mathrm{mg} / \mathrm{kg}$ body weight daily for 30 days caused significant prolongation of hexobarbital sleeping time (Table 4). This effect remains unexplained but it is just possible that benzene either inhibits the metabolism of hexobarbital or at this low dose of $50 \mathrm{mg} / \mathrm{kg}$ of body weight produces a narcotic effect that is additive to the narcotic effect of hexobarbital.

The activity of nitrobenzene as a potential stimulator of microsomal metabolism has not been experimentally checked yet.

This study indicates that nitrobenzene applied for a long time at low doses stimulates the activity of some microsomal enzymes (Table 2) and diminishes the antipyretic effect of phenacetin in yeast-fevered rats (Figure). The biological activity of nitrobenzene needs further study.

Have our results any significance for industrial toxicology? To answer this question we should compare the doses of the compounds applied in this study with threshold limit values of occupational exposure.

The maximal allowable doses are $35 \mathrm{mg}, 35 \mathrm{mg}$, and $100 \mathrm{mg}$ of aniline, nitrobenzene, and benzene, respectively, per man daily, i.e., $0.5-1.5 \mathrm{mg} / \mathrm{kg}$ of body weight (American Conference of Governmental Industrial Hygienists, 1972).

Rats are about 50 times less sensitive to aniline than man (Jenkins, Robinson, Gellatly, and Salmond, 1972) but there are no data on the basis of which we could say how tolerant rats are to nitrobenzene and benzene in comparison with man.

The aniline dose of $50 \mathrm{mg}$ per $\mathrm{kg}$ body weight of a rat used in this study corresponds to an aniline dose of about $70 \mathrm{mg}$ per man. Hence conclusions from this study may have some value for industrial toxicology. 

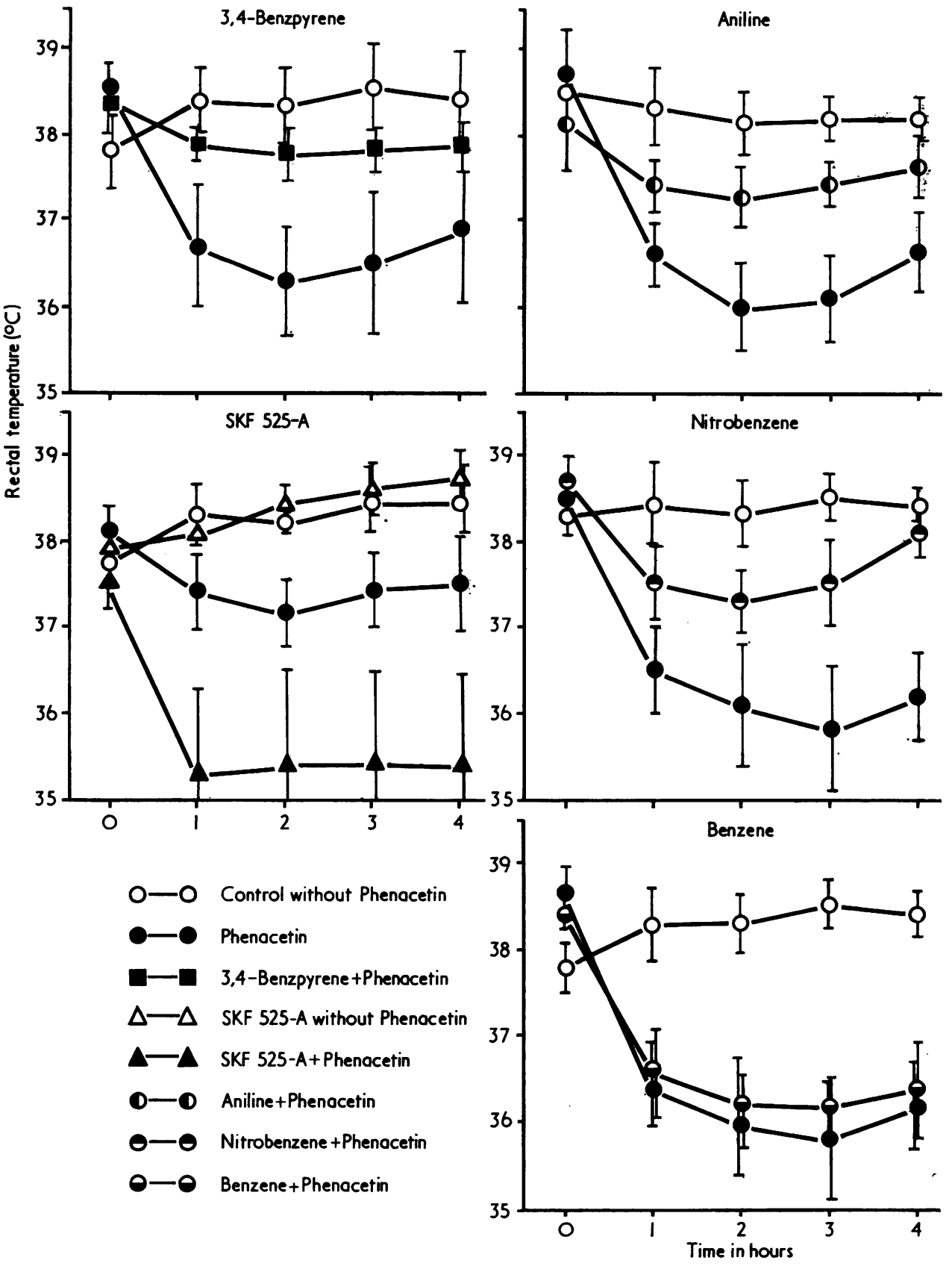

FIGURE Effect of prolonged exposure of rats to aniline, nitrobenzene, and benzene $(50 \mathrm{mg} / \mathrm{kg}$ body weight daily for 30 days) on the antipyretic activity of phenacetin. Animals treated with 3,4-benzpyrene and SKF 525-A served as the reference controls. Before the test a fever was evoked by subcutaneous injection of yeast suspension. Phenacetin was administered at 0 time. Groups untreated with phenacetin were included to ensure that (1) the temperature response to yeast suspension remained constant during the test time and (2) SKF 525-A alone had no antipyretic action at the dose used. Each group consisted of five rats. Vertical bars represent the standard deviation of the mean. For other details see the method described in the text. 
This study was supported in part by the US Public Health Service under Polish-American Agreement 05-013-2 for the Occupational Health Program.

Thanks are due to Dr. Krystyna Knobloch and Mr. J. Majka for performing the temperature tests and to Mrs. Helena Platak for technical assistance. SKF 525-A was kindly supplied by Smith, Kline, and French Overseas Co., Philadelphia, Pa.

Parts of this paper were presented at the 9th and 10th Annual Meetings of the Polish Biochemical Society (Katowice, 8-11 September 1971 and Poznań, 21-23 September 1972).

\section{References}

American Conference of Governmental Industrial Hygienists (1972). Documentation of the Threshold Limit Values for Substances in Workroom Air, edited by H. B. Elkins, 3rd edition. ACGIH, Cincinnati, Ohio.

Cochin, J. and Axelrod, J. (1959). Biochemical and pharmacological changes in the rat following chronic administration of morphine, nalorphine and normorphine. Journal of Pharmacology and Experimental Therapeutics, 125, 105-110.

Conney, A. H. and Burns, J. J. (1963). Induced synthesis of oxidative enzymes in liver microsomes by polycyclic hydrocarbons and drugs. Advances in Enzyme Regulation, 1, 189-214.

- Sansur, M., Soroko, F., Koster, R., and Burns, J. J. (1966). Enzyme induction and inhibition in studies on the pharmacological actions of acetophenetidin. Journal of Pharmacology and Experimental Therapeutics, 151, 133-138.

Cornish, H. H., Wilson, C. E., and Abar, E. L. (1970). Effect of foreign compounds on liver microsomal enzymes. American Industrial Hygiene Association Journal, 31, 605-608.

Dewaide, J. H. and Henderson, P. Th. (1968). Hepatic $\mathrm{N}$-demethylation of aminopyrine in rat and trout. Biochemical Pharmacology, 17, 1901-1907.

Dutkiewicz, T., Piotrowski, J., and Kęsy-Dąbrowska, I. (1964). Chemical Investigation of Biological Material in Industrial Toxicology, pp. 108-112. PZWL, Warsaw (in Polish).

Fouts, J. R. and Brodie, B. B. (1957). The enzymatic reduction of chloramphenicol, p-nitrobenzoic acid and other aromatic nitro compounds in mammals. Journal of Pharmacology and Experimental Therapeutics, 119, 197-207.

Gillette, J. R. (1966). Biochemistry of drug oxidation and reduction by enzymes in hepatic endoplasmic reticulum. Advances in Pharmacology, 4, 219-261.
Gonasun, L. M., Witmer, C., Kocsis, J. J., and Snyder, R. (1973). Benzene metabolism in mouse liver microsomes. Toxicology and Applied Pharmacology, 26, 398-406.

Holtzman, J. L. and Gillette, J. R. (1969). Effect of dietary orotic acid and adenine sulphate on hepatic microsomal enzymes in male and female rats. Biochemical Pharmacology, 18, 1927-1933.

Jenkins, F. P., Robinson, J. A., Gellatly, J. B. M., and Salmond, G. W. A. (1972). The no-effect dose of aniline in human subjects and a comparison of aniline toxicity in man and the rat. Food and Cosmetics Toxicology, 10, 671-679.

Kato, R., Chiesara, E., and Vassanelli, P. (1962). Increased activity of microsomal strychnine-metabolizing enzyme induced by phenobarbital and other drugs. Biochemical Pharmacology, 11, 913-922.

Lal, H., Puri, S. K., and Fuller, G. C. (1970). Impairment of hepatic drug metabolism by carbon tetrachloride inhalation. Toxicology and Applied Pharmacology, 16, 35-39.

Lowry, O. H., Rosebrough, N. J., Farr, A. L., and Randall, R. J. (1951). Protein measurement with the Folin phenol reagent. Journal of Biological Chemistry, 193, 265-275.

Lublina, E. I., Minkina, N. A., and Rylova, M. L. (1971). Adaptation to Industrial Poisons as a Phase of Intoxication, pp. 140-141. Medicina, Leningrad (in Russian).

Minkina, N. A., Lublina, E. I., Chekunova, M. P., and Dobrynina, V. V. (1970). The possible manifestations of the adaptation of organism to action of industrial poisons. In Current Topics of Industrial Toxicology, edited by N. V. Lazarev, A. A. Golubev, and E. T. Lihin, pp. 83-93. Ministry of Health, U.S.S.R., Leningrad (in Russian).

Nash, T. (1953). The colorimetric estimation of formaldehyde by means of the Hantzsch reaction. Biochemical Journal, 55, 416-421.

Piotrowski, J. (1971). The Application of Metabolic and Excretion Kinetics for the Problems of Industrial Toxicology. U.S. Government Printing Office, Washington, D.C.

Rickert, D. E. and Fouts, J. R. (1970). Benzpyrene pretreatment changes the kinetics and pH optimum for aniline hydroxylation in vitro, but not these for benzphetamine demethylation in vitro by rat liver microsomes. Biochemical Pharmacology, 19, 381-390.

Salm, J. (1958). Determination of aniline and p-aminophenol in blood. Medycyna Pracy, 9, 457-462. (in Polish).

Received for publication 8 February 1973 Accepted for publication 1 February 1974 